Article

\title{
Long-Term Impacts of Weather Conditions on Indoor Radon Concentration Measurements in Switzerland
}

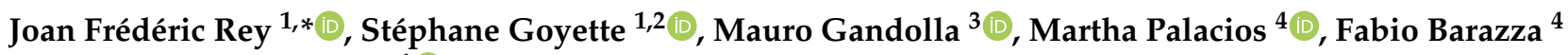 \\ and Joëlle Goyette Pernot $^{1}$ (D)
}

1 Transform Institute, Western Swiss Centre for Indoor Air Quality and Radon (croqAIR), School of Engineering and Architecture of Fribourg, HES-SO University of Applied Sciences and Arts Western, 1700 Fribourg, Switzerland; stephane.goyette@unige.ch (S.G.); Joelle.Goyette@hefr.ch (J.G.P.)

2 Institute for Environmental Sciences, University of Geneva, Blvd Carl Vogt 66, 1205 Geneva, Switzerland

3 ECONS SA, 6934 Bioggio, Switzerland; mauro.gandolla@econs.ch

4 Federal Office of Public Health, 3097 Liebefeld, Switzerland; martha.palacios@bag.admin.ch (M.P.) fabio.barazza@bag.admin.ch (F.B.)

* Correspondence: joanfrederic.rey@hefr.ch; Tel.: +41-78-696-7090

Citation: Rey, J.F.; Goyette, S.; Gandolla, M.; Palacios, M.; Barazza,

F.; Goyette Pernot, J. Long-Term Impacts of Weather Conditions on Indoor Radon Concentration Measurements in Switzerland. Atmosphere 2022, 13, 92. https:// doi.org/10.3390/atmos13010092

Academic Editor: Antoaneta Ene

Received: 16 December 2021

Accepted: 4 January 2022

Published: 7 January 2022

Publisher's Note: MDPI stays neutral with regard to jurisdictional claims in published maps and institutional affiliations.

Copyright: (C) 2022 by the authors Licensee MDPI, Basel, Switzerland. This article is an open access article distributed under the terms and conditions of the Creative Commons Attribution (CC BY) license (https:// creativecommons.org/licenses/by/ $4.0 /)$.

\begin{abstract}
Radon is a natural and radioactive gas that can accumulate in indoor environments. Indoor radon concentration (IRC) is influenced, among other factors, by meteorology, which is the subject of this paper. Weather parameters impact indoor radon levels and have already been investigated, but rarely in Switzerland. Moreover, there is a strong need for a better understanding of the radon behaviour inside buildings in Switzerland for public health concerns as Switzerland is a radon prone area. Based on long-term, continuous, and hourly radon measurements, radon distributions classified according to different weather event definitions were investigated and then compared at three different study sites in Western Switzerland. Outdoor temperature influences the most indoor radon, and it is globally anti-correlated. Wind influences indoor radon, but it strongly depends on intensity, direction, and building characteristics. Precipitation influences periodically indoor radon levels relatively to their intensity. Atmospheric pressure and relative humidity do not seem to be huge determinants on IRC. Our results are in line with previous findings and provide a vivid example in Western Switzerland. This paper underlines the different influence complexities of radon, and the need to communicate about it within the broader public and with construction professionals, to raise awareness.
\end{abstract}

Keywords: radon; indoor radon levels; meteorological parameters; Switzerland; Jura mountains; public health concern

\section{Introduction}

Radon-222 is an odourless, colourless, and tasteless radioactive natural noble gas, with a half-life of 3.82 days [1]. Radon-222 is a decay product of uranium-238; it is naturally present in the earth's mantle and crust. Radon diffuses from the crust to the surface through pores and cracks [2,3]. In Switzerland, local and regional geology influence the presence (or not) of radon, as demonstrated by Kroppat et al. [4]. Sedimentary rocks, such as limestone and shale, can lead to a low to medium risk of IRC, while granitic formation can lead to a high risk of IRC [5]. In Switzerland, radon concentration potential is higher in some alpine regions and in the Jura mountains [6]. While many Alpine regions are composed by granitic rocks, Jura mountains are mostly composed by limestone [7]. Both of these regions are radon prone areas [3,4,7-9]. Soil types have a strong impact on radon diffusion and exhalation. Variations in the soil porosity and, thus, on the moisture capacity, modulate the radon emanation, diffusion, and exhalation [10]. Radon may eventually diffuse into indoor environments [2,3]. Radon access into the indoor environment through tightness defaults in a built-up surface with ground contact. These paths are multiple: through walls and floor cracks, pipes, plumbing, joints, leaky basement doors [3,11]. In indoor 
environments, radon can accumulate and reach highly harmful concentrations because of continuous radon decay products. Radon gas is the second leading cause of lung cancer after tobacco. Thus, it is a major concern to public health. Radon is responsible for 8 to $10 \%$ of lung cancers in Switzerland and 3 to $14 \%$ worldwide $[2,3,8,12,13]$. Each year, 200 to 300 lung cancer deaths are imputable to indoor radon exposure in Switzerland [3].

Since the World Health Organization's (WHO) report on health impacts, 1993, Swiss federal authorities have regulated radon, problematic with a new legal basis, composed by the Radiological Protection Act (RPA of the Swiss federal constitution), adopted in 1991, and the Radiological Protection Ordinance (RPO of the Federal Council) adopted in 1994, fully updated in 2017, and enforced on 1 January, 2018. Since the beginning of the 1990s, 250,000, IRC measurements, performed by Swiss authorities, have been carried out in 150,000 buildings ( $6 \%$ of the building stock). From these measurements, it was observed that many building are standing over the reference value of $300 \mathrm{~Bq} / \mathrm{m}^{3}$, and will need to be renovated someday. The reference value of $300 \mathrm{~Bq} / \mathrm{m}^{3}$ comes from epidemiological studies [14] and is an international consensus [2,15,16]. The Federal Office of Public Health $(\mathrm{FOPH})$ leads federal action plans on radon in order to support the implementation of legislation [12,13].

\subsection{Literature Review}

It is known that IRC is influenced by geological factors (radon emanation, diffusion, and exhalation, ground porosity, and permeability), building characteristics (tightness defaults in built-up surfaces with ground contact, indoor air renewal, building airtightness, and thermal isolation), occupant behaviours, and also by meteorological conditions (cf. Figure 1). Amongst these four main influences on IRC, meteorological conditions are this paper's main object of study. This study follows a previous study [17], which highlights the influence of weather conditions on IRC. Weather conditions have a significant influence on radon concentrations in the atmospheric boundary layer and, consequently, inside buildings and on radon exhalation. It has been shown that variations in atmospheric conditions, for instance, surface air pressure, wind speed and direction, precipitation, drought conditions and frost, have an impact on radon exhalation [18].

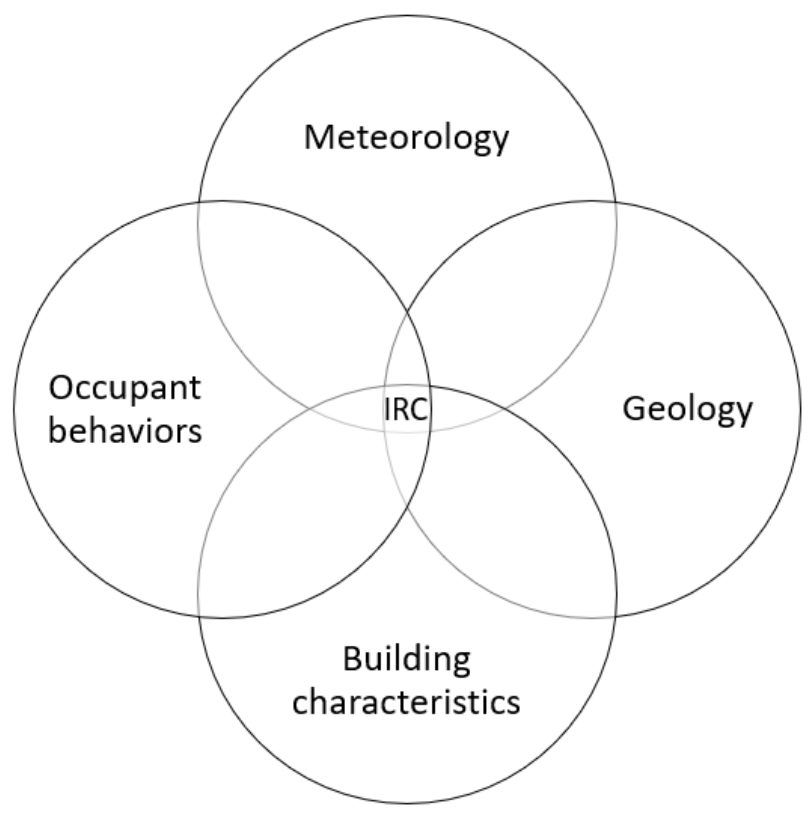

Figure 1. IRC is directly influenced by local geology, occupant behaviours, building characteristics, and meteorology - the latter aspect being the main focus of this study. Others influences on IRC cannot be specifically identified, but cannot be ignored. 
The outdoor surface air temperature impacts on IRC have largely been investigated (cf. Table 1). According to most studies, IRC is anti-correlated with air temperature in closed environments [4,19-22]. For both studies led by Groves-Kirkby [23,24], the studied environments were unused basements from public buildings, always closed, and had very few visits over the study time. These indoor environments are isolated from outdoor weather and are therefore not driven by its variation $[23,24]$.

Table 1. Synthesis of outdoor air temperature influences on IRC highlighted in some literature. (Ref.: references; M.: measurements; Temp: temperature).

\begin{tabular}{|c|c|c|c|c|c|c|c|}
\hline Author(s) & Ref. & Year & Country & M. Type & M. Length & Local Type & Influence Temp. on IRC \\
\hline Hubbard et al. & [25] & 1992 & Sweden & Active & 10 months & Two similar houses & Correlation \\
\hline Yu et al. & [26] & 1996 & Hong Kong & Active & 5 months & Living rooms & Significant effects \\
\hline Ramola et al. & [19] & 2000 & India & Active & $24 \mathrm{~h}$ & $\begin{array}{c}\text { Mud house } \\
\text { Concrete house }\end{array}$ & $\begin{array}{c}\text { Correlation } \\
\text { Anti-correlation }\end{array}$ \\
\hline Rowe et al. & [20] & 2002 & UK & Passive & $\begin{array}{l}3 \text { days } \\
1 \text { month }\end{array}$ & Main room & Anti-correlation \\
\hline Groves-Kirkby. & [23] & 2006 & UK & Active & $>1$ year & Cellars & Correlation \\
\hline Groves-Kirkby. & [24] & 2012 & UK & Active & $>2$ years & Cellars & Correlation \\
\hline Kropat et al. & [4] & 2014 & Switzerland & Passive & 3 months & Multiple types & Anti-correlation \\
\hline Xie et al. & [22] & 2015 & USA & Active & 14 months & $\begin{array}{l}\text { Ground floor } \\
\text { Basement }\end{array}$ & Anti-correlation \\
\hline Curado et al. & [21] & 2017 & Portugal & Active & 3 weeks & $\begin{array}{c}\text { Living rooms } \\
\text { kitchen Bedrooms }\end{array}$ & Anti-correlation \\
\hline Rey et al. & [17] & 2021 & Switzerland & Active & $>1$ year & Living room & Anti-correlation \\
\hline
\end{tabular}

The literature shows that temperature differences between indoor and outdoor environments have a huge influence on IRC $[20,22,24,27]$. While indoor inhabited space temperature remain constant throughout the day, outdoor temperatures vary, inducing a pressure difference between the indoor and outdoor environment. While outdoor temperature is lower than indoor temperature, the air density difference between outdoors and indoors induces a depressurization at the building base, resulting in air infiltration from outside, and from the ground to indoor environment. This consequence is known as stack effect [28]. During winter, the greater temperature difference between outdoors and indoors enhances the stack effect. Conversely, during the summer, a higher temperature outdoors than indoors may cause a reverse stack effect, which induces an overpressure at the building base. This effect will prevent air infiltration from outside and from the ground.

Numerous studies have reported on the link between atmospheric pressure and IRC (cf. Table 2). Table 2 highlights the different results of atmospheric pressure influence on IRC in different indoor environments. According to Table 2, atmospheric pressure influences on IRC seem to anti-correlate in concrete and lived spaces, and correlate in basements and mud-houses. Moreover, Pearson et al. (1966) show that atmospheric pressure variations influence terrain exhalation of radon. Another important aspect is the pressure differences between outdoor and indoor environments that impact IRC [22,23,29-31]. In addition to temperature, when the indoor environment is under-balanced compared to the outdoor environment, infiltration of radon will increase due to the stack effect, and vice-versa. They $[22,23,29-31]$ agree on the influence of pressure differences between outdoor and indoor environments on IRC. The intensity of this influence is mainly driven by indoor heating and outdoor temperatures [23]. 
Table 2. Synthesis of atmospheric pressure influences on IRC highlighted in a selected literature. (Ref.: references; M.: measurements; Pres: pressure).

\begin{tabular}{|c|c|c|c|c|c|c|c|}
\hline Author(s) & Ref. & Year & Country & M. Type & M. Length & Local Type & Influence Pres. on IRC \\
\hline Hintenlang et al. & [31] & 1992 & USA & Active & 4 days & Whole building & Correlation \\
\hline Yu et al. & [26] & 1996 & Hong Kong & Active & 5 months & Living rooms & Probably a link \\
\hline Robinson et al. & {$[30]$} & 1997 & - & Active & 7 days & Basement & Correlation \\
\hline Ramola et al. & [19] & 2000 & India & Active & $24 \mathrm{~h}$ & $\begin{array}{l}\text { Mud house } \\
\text { Concrete house }\end{array}$ & No correlation \\
\hline Marley & [32] & 2001 & - & Active & 4 months & 4 buildings & Link \\
\hline Kitto et al. & [27] & 2005 & USA & $\begin{array}{l}\text { Active } \\
\text { Passive }\end{array}$ & 15 months & $\begin{array}{l}\text { Bedrooms } \\
\text { Basement }\end{array}$ & No link \\
\hline Groves-Kirkby. & {$[24]$} & 2012 & UK & Active & $>2$ years & Cellars & No correlation \\
\hline Xie et al. & [22] & 2015 & USA & Active & 14 months & $\begin{array}{c}\text { Ground floor } \\
\text { Basement }\end{array}$ & Correlation \\
\hline Rey et al. & [17] & 2021 & Switzerland & Active & $>1$ year & Living room & Anti-correlation \\
\hline
\end{tabular}

Precipitation has a strong impact on IRC as shown in Table 3. Surface water infiltration has a strong impact on the soil moisture content and, thus, on the radon ground exhalation, so that negative correlations between radon ground exhalation and "strong precipitation" or snow melt have been reported [27]. Therefore, during rainfall, soils become watertight and radon cannot exhale from soils, except underneath buildings. During precipitation events, IRC thus increases [20,23,24,26,33,34].

Table 3. Synthesis of precipitation influences on IRC highlighted in a selected literature. (Ref.: references; M.: measurements; Prec: precipitation).

\begin{tabular}{|c|c|c|c|c|c|c|c|}
\hline Author(s) & Ref. & Year & Country & M. Type & M. Length & Local Type & Influence Prec. on IRC \\
\hline Mose et al. & [33] & 1991 & USA & Passive & 2 summers & $\begin{array}{l}\text { Hundred of } \\
\text { buildings }\end{array}$ & Correlation \\
\hline Yu et al. & [26] & 1996 & Hong Kong & Active & 5 months & Living rooms & Significant effects \\
\hline Rowe et al. & [20] & 2002 & UK & Passive & $\begin{array}{l}3 \text { days } \\
1 \text { month }\end{array}$ & Main room & Link \\
\hline Kitto et al. & [27] & 2005 & USA & $\begin{array}{l}\text { Active } \\
\text { Passive }\end{array}$ & 15 months & $\begin{array}{l}\text { Bedrooms } \\
\text { Basement }\end{array}$ & Anti-correlation \\
\hline Groves-Kirkby. & [23] & 2006 & UK & Active & >1 year & Cellars & Correlation \\
\hline Steck et al. & {$[34]$} & 2009 & USA & Passive & 17 years & 98 houses & Correlation \\
\hline Groves-Kirkby. & [24] & 2012 & UK & Active & $>2$ years & Cellars & $\begin{array}{l}\text { Minimal (anti-) } \\
\text { correlation }\end{array}$ \\
\hline Rey et al. & [17] & 2021 & Switzerland & Active & $>1$ year & Living room & Strong link \\
\hline
\end{tabular}

Table 4-synthesis of outdoor air's relative humidity influences on IRC. Results may differ, according to the context of the studies. Yu et al. (1996) show that outdoor air relative humidity is correlated with the amount of rainfall; therefore, it is difficult to identify the effects of this parameter alone [26].

Wind episodes induce a pressure difference field around buildings. According to the wind speed and direction, this pressure field may vary and further induce dynamical pressure differences between the outdoor and indoor environments, which will thus affect IRC [35-37]. Table 5 highlights the wind effects on IRC. Globally, wind undeniably influences IRC, but results may vary as any building presents its own characteristics. 
Table 4. Synthesis of outdoor relative humidity influences on IRC highlighted in a selected literature.

(Ref.: references; M.: measurements; RH: relative humidity).

\begin{tabular}{|c|c|c|c|c|c|c|c|}
\hline Author(s) & Ref. & Year & Country & M. Type & M. Length & Local Type & Influence RH. on IRC \\
\hline Yu et al. & [26] & 1996 & Hong Kong & Active & 5 months & Living rooms & Probably a link \\
\hline Ramola et al. & [19] & 2000 & India & Active & $24 \mathrm{~h}$ & $\begin{array}{l}\text { Mud house } \\
\text { Concrete house }\end{array}$ & Correlation \\
\hline Groves-Kirkby. & {$[24]$} & 2012 & UK & Active & $>2$ years & Cellars & $\begin{array}{l}\text { Minimal (negative) } \\
\text { correlation }\end{array}$ \\
\hline Xie et al. & {$[22]$} & 2015 & USA & Active & 14 months & $\begin{array}{l}\text { Ground floor } \\
\text { Basement }\end{array}$ & Anti-correlation \\
\hline Curado et al. & {$[21]$} & 2017 & Portugal & Active & 3 weeks & $\begin{array}{l}\text { Living rooms } \\
\text { kitchen Bedrooms }\end{array}$ & Correlation \\
\hline
\end{tabular}

Table 5. Synthesis of wind events on IRC highlighted in a selected literature. (Ref.: references; M.: measurements).

\begin{tabular}{|c|c|c|c|c|c|c|c|}
\hline Author(s) & Ref. & Year & Country & M. Type & M. Length & Local Type & Influence Wind on IRC \\
\hline Buchli et al. & [38] & 1985 & Switzerland & Active & 1 to 3 weeks & 3 homes & Anti-correlation \\
\hline Yu et al. & [26] & 1996 & Hong Kong & Active & 5 months & Living rooms & Strong link \\
\hline Marley & [32] & 2001 & - & Active & 4 months & 4 buildings & Link \\
\hline Miles et al. & [39] & 2001 & $\begin{array}{c}\text { UK } \\
\text { Germany }\end{array}$ & Passive & 1 year & $\begin{array}{l}3 \text { homes } \\
1 \text { home }\end{array}$ & Strong link \\
\hline Rowe et al. & [20] & 2002 & UK & Passive & $\begin{array}{l}3 \text { days } \\
1 \text { month }\end{array}$ & Main room & Strong link \\
\hline Kitto et al. & [27] & 2005 & USA & $\begin{array}{l}\text { Active } \\
\text { Passive }\end{array}$ & 15 months & $\begin{array}{l}\text { Bedrooms } \\
\text { Basement }\end{array}$ & No link \\
\hline Xie et al. & [22] & 2015 & USA & Active & 14 months & $\begin{array}{c}\text { Ground floor } \\
\text { Basement }\end{array}$ & Anti-correlation \\
\hline Rey et al. & [17] & 2021 & Switzerland & Active & $>1$ year & Living room & Strong link \\
\hline
\end{tabular}

Finally, some studies have explored the influences of a combination of meteorological parameters on IRC. Based on a non-exhaustive literature review, outdoor air temperature, precipitation, and wind seem to be the most influential drivers on IRC [20,22,24,26,27,34].

In Switzerland, a few radon-related studies have been conducted since the mid-1980s, focusing on health impacts [7,40], building characteristics [41,42], influences of environmental parameter on IRC $[4,38,43]$, and modelling and mapping [4,44-46], indicating some concern over radon-related topics and its impacts being ubiquitous in Switzerland.

\subsection{Aim of the Study}

Remediation in Switzerland's housing stock is necessary, according to FOPH's willingness to decrease radon exposition. To that end, radon short-term (1 week) measurements must be carried out in the existing housing stock in different contexts: after an official measurement, during a real-estate transaction, or before a building remediation and transformation, so that radon risk must be taken upstream in a project. With such short-measurements, professional interpretations of measurements must be based on strong knowledge. This article contributes towards the knowledge on weather influences on radon measurements.

This study investigated two long-term radon time-series, carried out in two distinct regions in the Jura Arc, collected under the Franco-Swiss Interreg project Jurad-BAT. These times-series were compared to a long-term radon time-series carried out in the Swiss Plateau at the request of the FOPH. The aim was to explore long-term impacts of weather conditions on IRC, in order to ensure the result interpretations of short-time radon measurements in different environments. Thus, professionals may recommend solutions depending on the building context, in order to optimize the radon-risk management and reduce the radon 
exposure risk. In Switzerland, there is a strong need for a better understanding of the radon behaviour within buildings (a public health concern).

Based on the active, continuous, long-term radon (and weather) hourly measurements, in three different environments, the innovative approach of this study provides an overview of the influence of the time-evolution of weather conditions on IRC measurements at three different locations, differing by their geographical and geological characteristics, radon exposure, occupant behaviour, and building characteristics (cf. Figure A1 \& Table A1).

The objective was to answer the following questions: what are the impacts of weather conditions on IRC at three different locations in Switzerland? Is there a significant difference of weather influence on IRC between sites and spaces? Can the results be extended to the whole of Switzerland? Are there weather conditions during which IRC is more predictable? The ultimate purpose of this paper is to address specific recommendations for radon professionals. To provide insight to these questions, this study explores the link between measured IRC and a number of meteorological variables separately at these sites.

\section{Materials and Methods}

IRC was measured in $\mathrm{Bq} / \mathrm{m}^{3}$ by active sensors RadonMappers and an AlphaGUARD in three study sites (cf. Figure A1, Tables A1 and A2). Sensor characteristics are synthesized in Table A3.

Study site A, located in Bevaix near lake Neuchâtel, is a family house built between 1895 and 1900 and renovated in 2001. This building is airtight; there is concern that this building has radon entering from the basement and office grounds. In the basement, the floor is a cement sub-slab, while in the office, there is a parquet on natural ground.

Study site B, located in La Brévine in the Jura mountains, is an old Jura farmhouse built during the 18th century. This building is the less airtight building in this study and natural ground is omnipresent: living space consists of a parquet on natural ground. Site $B$ is a radon prone building.

Study site C, located in Gunzgen on the Swiss Plateau, is a mid-18th century municipal building renovated in 1976. with a concrete sub-slab, this building is quite airtight.

The climate is very different between each study site. Bevaix and Gunzgen are both located on the Swiss Plateau, but Bevaix's climate is influenced by the proximity of Lake Neuchâtel. La Brévine is located within the Jura mountains at an altitude of 1050 m.a.s.l., and the topographical context allows temperatures to sink below $-30^{\circ} \mathrm{C}$ frequently during winter. More building spaces and building characteristics are displayed in Tables 6 and A1.

Table 6. Built characteristics of studied spaces.

\begin{tabular}{|c|c|c|c|c|}
\hline Space Type & Characteristics & $\begin{array}{c}\text { Building A } \\
\text { Bevaix }\end{array}$ & $\begin{array}{l}\text { Building B } \\
\text { La Brévine }\end{array}$ & $\begin{array}{c}\text { Building C } \\
\text { Gunzgen }\end{array}$ \\
\hline \multirow{4}{*}{ Occupied } & Name & Office & Sleeping room & Village hall \\
\hline & Floor & 0 & 0 & 0 \\
\hline & Ground floor & Parquet on natural ground & Parquet on natural ground & Concrete \\
\hline & Approx. surface & $16 \mathrm{~m}^{2}$ & Unknown & Unknown \\
\hline \multirow{4}{*}{ Unoccupied } & Name & Basement & Shed & Closet \\
\hline & Floor & -1 & 0 & 0 \\
\hline & Ground floor & Cement sub-slab & Natural floor & Concrete \\
\hline & Approx. surface & $12 \mathrm{~m}^{2}$ & Unknown & $1 \mathrm{~m}^{2}$ \\
\hline
\end{tabular}

At each study site, two sensors were installed: one in an occupied room and one in an unoccupied room (cf. Table 6). Occupied spaces were heated during winter season, unlike unoccupied spaces. Data were recorded every minutes (RadonMapper) and $10 \mathrm{~min}$ (AlphaGUARD), and these were then hourly averaged (cf. Table A3). To ease both insite and an inter-site comparisons, the observed data were standardized according to an annual reference distribution. Figure A2 illustrates the timeline of data acquisition and their respective standardization periods, through a Gantt diagram. 
For each study site, hourly-mean meteorological variables, coming from the nearest MeteoSwiss observation stations, uploaded through the online website IDAweb [47], are synthesized in Table A2, allowing for a statistical analysis between IRC and different thresholds of meteorological parameters.

To explore the impacts of air temperature on IRC, different thresholds, defined according to MeteoSwiss definitions, are used [48]. Potential connections between IRC and specific weather conditions are sought across seasons:

- $\quad$ Icy days: the daily maximum air temperature is lower than $0{ }^{\circ} \mathrm{C}$;

- $\quad$ Frost days: the daily minimum air temperature is lower than $0{ }^{\circ} \mathrm{C}$;

- $\quad$ Summer days: the daily maximum air temperature reaches $25^{\circ} \mathrm{C}$;

- $\quad$ Dog days: the daily maximum air temperature reaches $30^{\circ} \mathrm{C}$.

Different ranges of air relative humidity (0-25\%, 26-50\%, 51-75\%, 76-100\%) were used to compare the effects on IRC. As all data were normalized, different thresholds ( $-3 \sigma$, $-2 \sigma,-1 \sigma, 0 \sigma,+1 \sigma,+2 \sigma,+3 \sigma), \sigma$ being the standard deviation, were used to compare the effects of atmospheric pressure on IRC. Different types of precipitation events, as well as the lack of precipitation, were used to assess their influence on IRC. In the winter, rain, snow, and drought were considered, whereas in the summer, rain, thunderstorms, and drought were taken into account. IRC distributions during these events were then compared to the respective seasonal and annual averages.

To assess the effects of wind on IRC, both qualitative definitions and quantitative thresholds were used to define wind events. Classification of wind direction is based on the local wind rose. For the three study sites, the main wind directions were South-West and North-East [49]. Table 7 presents the syntheses of the main wind directions. Classification of wind intensity is based on different thresholds of standard deviations similar to the analysis of the atmospheric pressure.

Table 7. Main wind directions for the three study sites.

\begin{tabular}{cccc}
\hline Sites & & Eastern Winds & Western Winds \\
\hline A & Bevaix & $35^{\circ}-85^{\circ}$ & $225^{\circ}-285^{\circ}$ \\
B & La Brévine & $25^{\circ}-65^{\circ}$ & $205^{\circ}-275^{\circ}$ \\
C & Gunzgen & $25^{\circ}-75^{\circ}$ & $215^{\circ}-275^{\circ}$ \\
\hline
\end{tabular}

\section{Results}

For each study site, two spaces were simultaneously studied: an occupied and an unoccupied space. Occupied spaces were heated during the winter season. The three study sites were characterized by many different features, but shared indoor radon as a common feature.

The figures shown in this section present IRC distributions, according to different meteorological events, defined in the previous section. The recurrence of these events allow to visually identify only the relevant meteorological event influences on IRC.

\subsection{Temperature}

Annual and seasonal analyses were made between temperature variables and IRC at each study site. Figure 2 shows the IRC box-plots according to these temperature variables.

Measured IRC in the three occupied space sites (office, sleeping room, and village hall) indicate similar trends. Globally, IRC was lower during the summer than winter in occupied spaces. Moreover, IRC was lower during icy days than frost days and winter. In the summer, occupants are presumed to ventilate more frequently during warm weather conditions, especially during hot days. Moreover, the absence of the stack effect allows low IRC. These findings are confirmed by anti-correlations between outside air temperatures and indoor radon concentrations within occupied rooms. In contrast, during the winter, IRC was higher mostly due to an increased stack-effect caused by larger temperatures between indoor and outdoor environments. Thus, radon infiltration was enhanced in 
indoor environments. Contrary to expectations, IRC was lower during icy days than frost days at each study site. Icy days are days when temperatures do not exceed $0{ }^{\circ} \mathrm{C}$. It is very likely that radon is trapped in frozen ground and may not reach indoor environments.
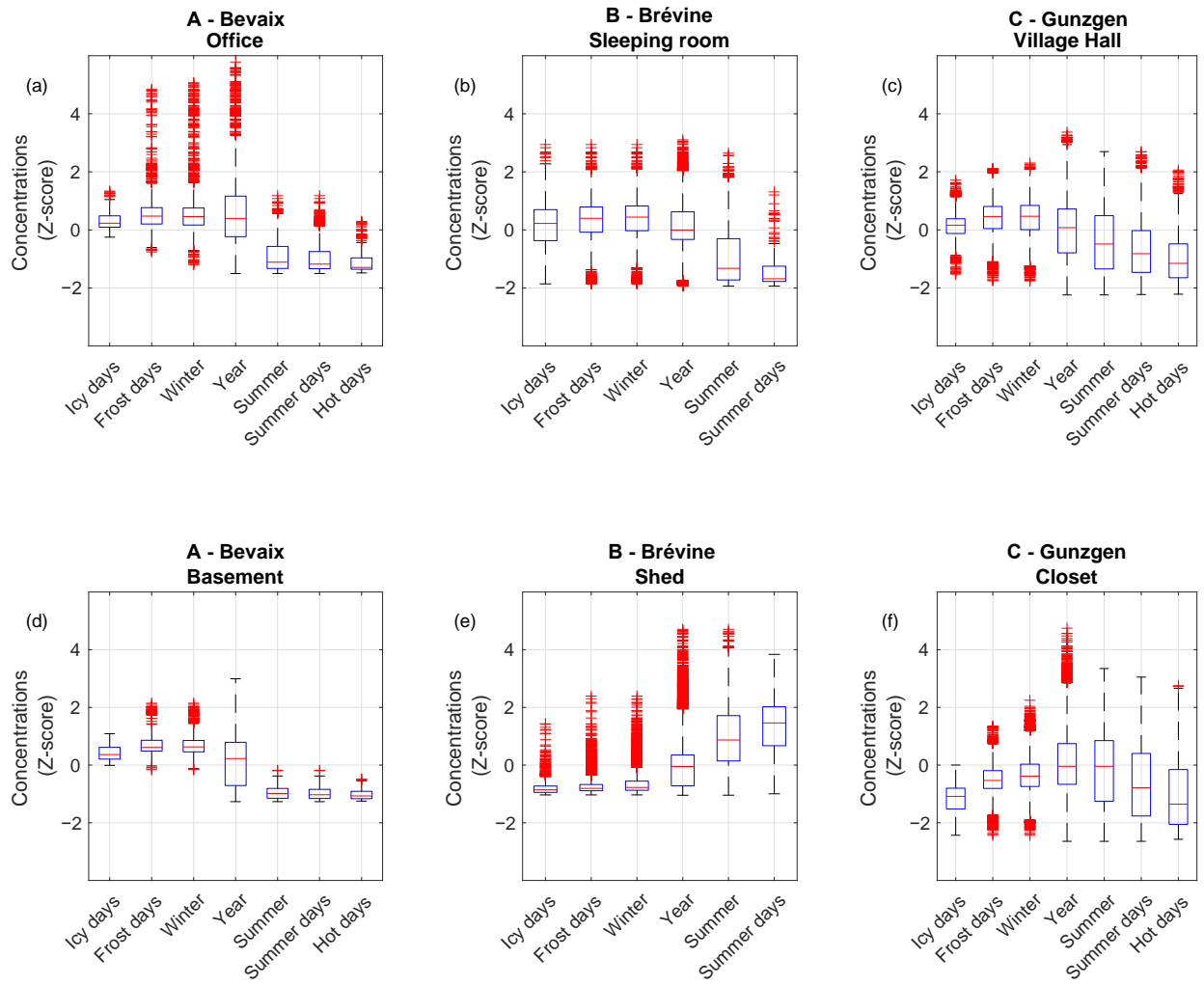

Figure 2. Box-plots synthesizing the impacts of outdoor air temperature on a yearly basis, summer and winter seasons, as well as for temperature thresholds on IRC at Bevaix (a,d), La Brévine (b,e), and Gunzgen $(\mathbf{c}, \mathbf{f})$. Occupied spaces are shown in $(\mathbf{a}-\mathbf{c})$ and unoccupied spaces in $(\mathbf{d}-\mathbf{f})$.

Results for unoccupied indoor spaces differed at each study site. In Bevaix, results were similar to occupied spaces. However, cellar window were open during the whole summer period. In winter, IRC was similar to the office ones, albeit with less "spread" high values. La Brévine's case study was unexpected, as opposed to other unoccupied space results. Shed IRC was higher during the summer than in the winter. It is worth noting that this shed is an uninsulated room-the floor is a wood parquet over a natural and permeable ground.

During the winter, the shed temperature is very close to outside temperature, causing a lack of stack effect in that room. During the summer, two assumptions could explain these results. Firstly, the shed temperature could be somehow higher than soil temperature, by a few degrees, causing an unexpected summer stack effect. Secondly, building ventilation, induced by opened windows for example, might strengthen this unexpected situation by generating air flow from the shed to other house's rooms. Thus, an abnormal summery stack effect induces greater IRC in the shed. These results highlight that La Brévine case study is very unusual.

Gunzgen's closet undergoes trends similar to Bevaix, except during the summer. The reason for this rather contradictory result is that Bevaix's basement cellar windows were open during the entire summer period, which was not the case within the closet. Located under the stairs, the indoor temperature remains lower than the outside temperature during the summer, while temperature is higher during the winter. Thus, during the winter, the stack effect is induced. 


\subsection{Atmospheric Pressure}

Surface atmospheric pressure induces variations in IRC (cf. Figure 3). Globally, occupied spaces present same tendencies, but without a clear pattern between summer and winter. During the summer, the lower the pressures, the lower the IRC, whereas in the winter, the lower the pressures, the higher the IRC.

In unoccupied spaces, winter results do not highlight differences between pressure levels. Generally, Bevaix's result are close to occupied space ones, whereas with La Brévine and Gunzgen, the results vary inversely to that of the occupied space results. Winter's IRC is lower than summer's in the shed and closet.

In light of these results, atmospheric pressure does not seem to be a huge determinant of IRC.
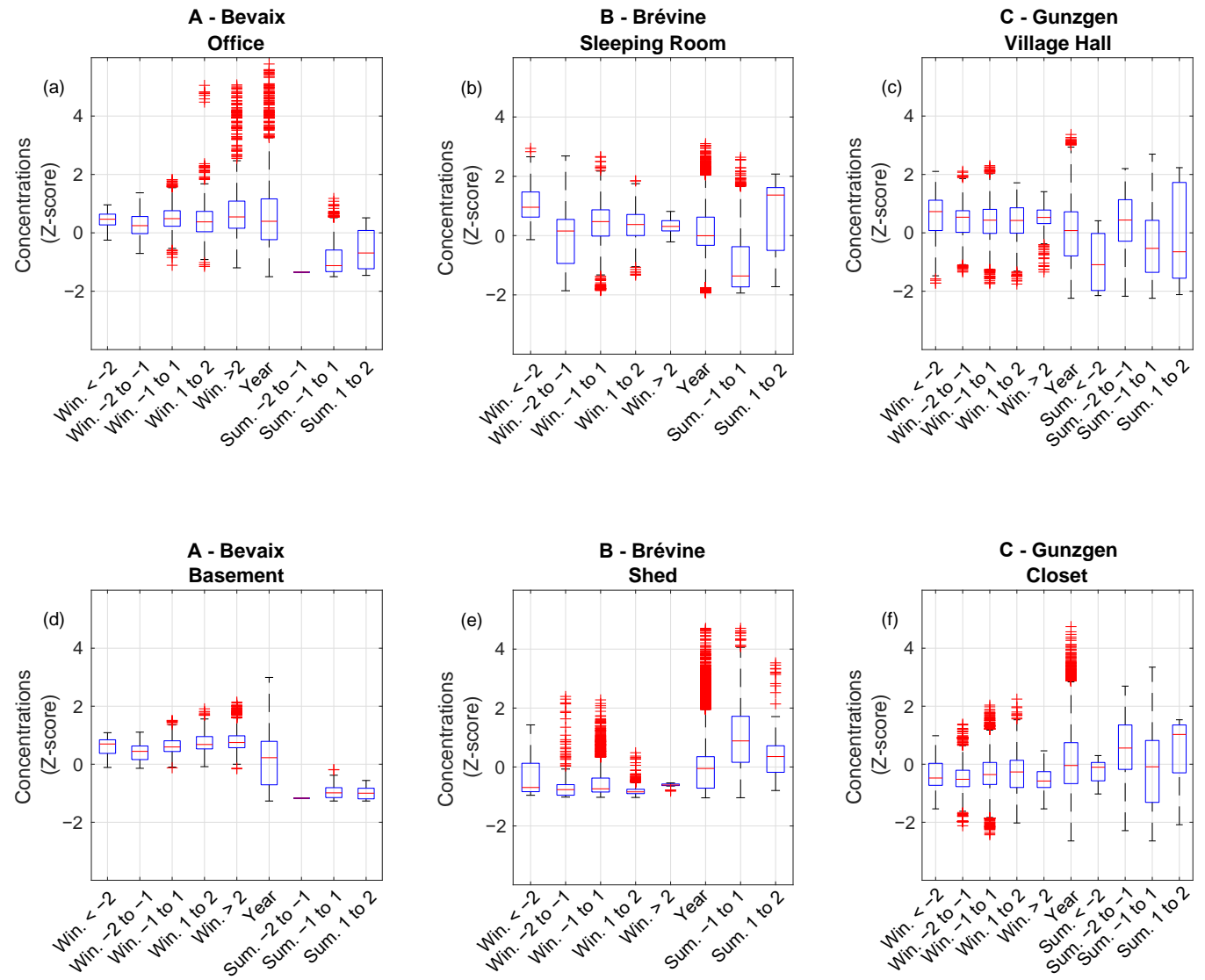

Figure 3. Box-plots synthesizing the impacts of atmospheric pressure on IRC at Bevaix (a,d), La Brévine $(\mathbf{b}, \mathbf{e})$, and Gunzgen $(\mathbf{c}, \mathbf{f})$. Occupied spaces are shown in $(\mathbf{a}-\mathbf{c})$ and unoccupied spaces in $(\mathbf{d}-\mathbf{f})$. Annual standard deviation threshold results are given for both winter and summer. Some of them are missing for summer because they did not occur.

\subsection{Precipitation}

Figure 4 illustrates that precipitation or the lack of precipitation influences IRC in the three study sites, although results differ among them. Everywhere, except in La Brévine's shed, summer is characterized by lower IRC than in the winter, especially during drought days. Conversely, during the summer, heavy rains, and thunderstorms, IRC seems to be higher. During the winter, rainfalls seem to make IRC rise, as do snow events (to a lesser extent).

These results are in good agreement with the hypothesis that precipitation events tighten the ground, except under the building, where ground remains dry, so that radon can still exhale. Moreover, other tendencies can be identified, such as seasonality and the stack effect. 

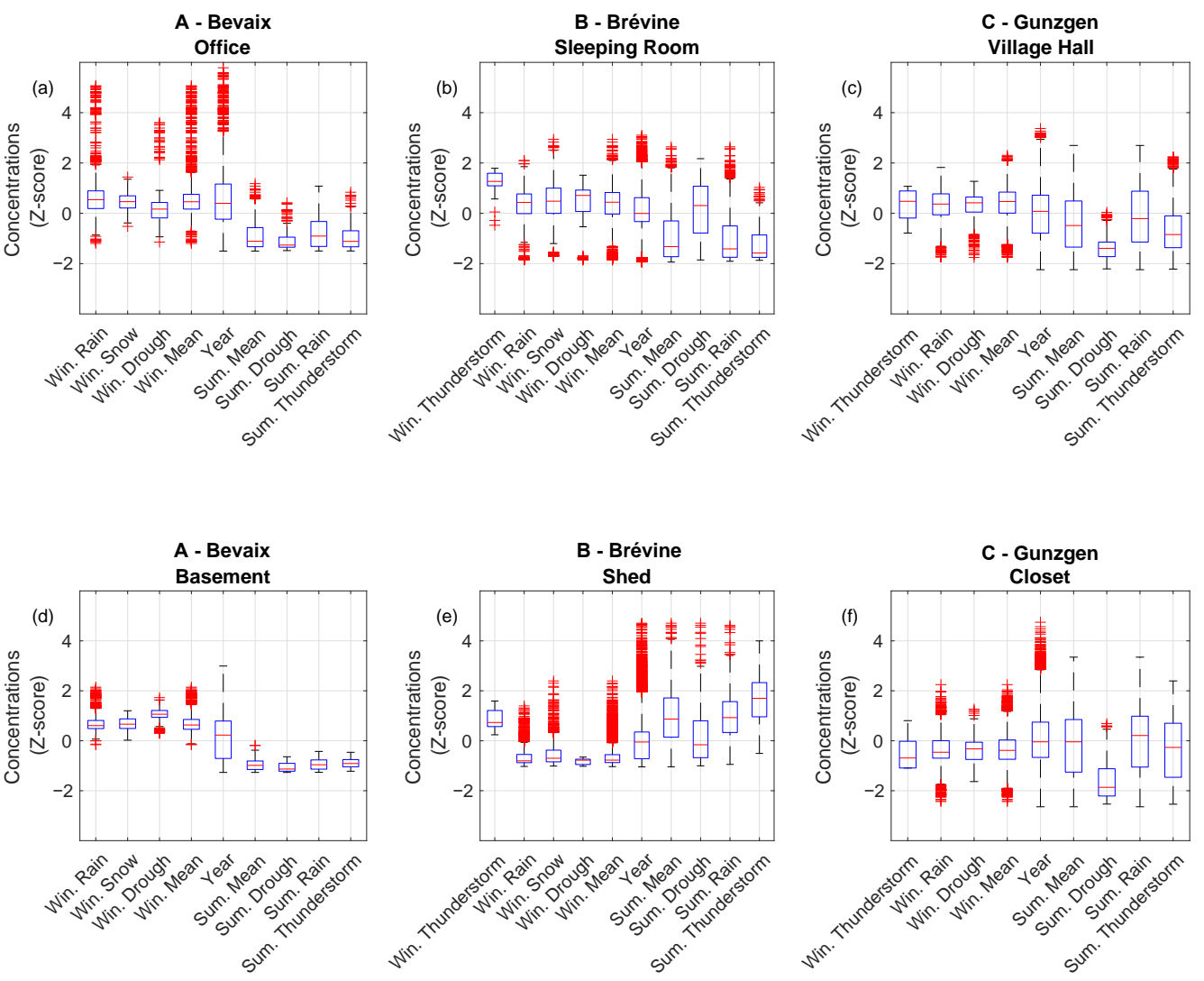

Figure 4. Box-plots synthesizing the impacts of precipitation on IRC at Bevaix $(\mathbf{a}, \mathbf{d})$, La Brévine $(\mathbf{b}, \mathbf{e})$, and Gunzgen $(\mathbf{c}, \mathbf{f})$. Occupied spaces are shown in $(\mathbf{a}-\mathbf{c})$ and unoccupied spaces in $(\mathbf{d}-\mathbf{f})$. Different precipitation events are given for both winter and summer.

\subsection{Relative Humidity}

Figure 5 shows variations of IRC according to the different ranges of outdoor air relative humidity. Similar to temperature, trends were almost globally similar at the three study sites, except in La Brévine's shed. IRC was higher during the winter than the summer, regardless of the outside RH level.

During the summer, IRC rose when outdoor RH rose. This trend might be linked to heavy rainfalls and thunderstorms. To validate this hypothesis, further studies should explore the co-influence of precipitation events and outdoor RH on IRC. La Brévine's shed is again an exception: radon levels were lower in winter than in the summer. However, IRC rose while outdoor $\mathrm{RH}$ level rises for both summer and winter.

Globally, during winter, for the three occupied spaces, IRC were higher while outdoor $\mathrm{RH}$ levels rose. This can be presumably attributed to rainy days.

\subsection{Winds}

\subsubsection{Easterly Winds}

Wind events induce a differential pressure field across the facades of a building [35-37]. This pressure difference further influences IRC. Figure 6 illustrates how easterly winds influence IRC in each study site. Globally, tendencies are similar between each study site, except in La Brévine's shed. During the summer, occupied space IRC vary according to easterly wind speed, but these results differ in the details among study sites. In unoccupied spaces, high easterly winds caused IRC to decrease.

During the winter, lower easterly winds induced higher IRC for both occupied and unoccupied spaces. However, it seems that eastern winds did not influence IRC much, especially during high wind speed. 

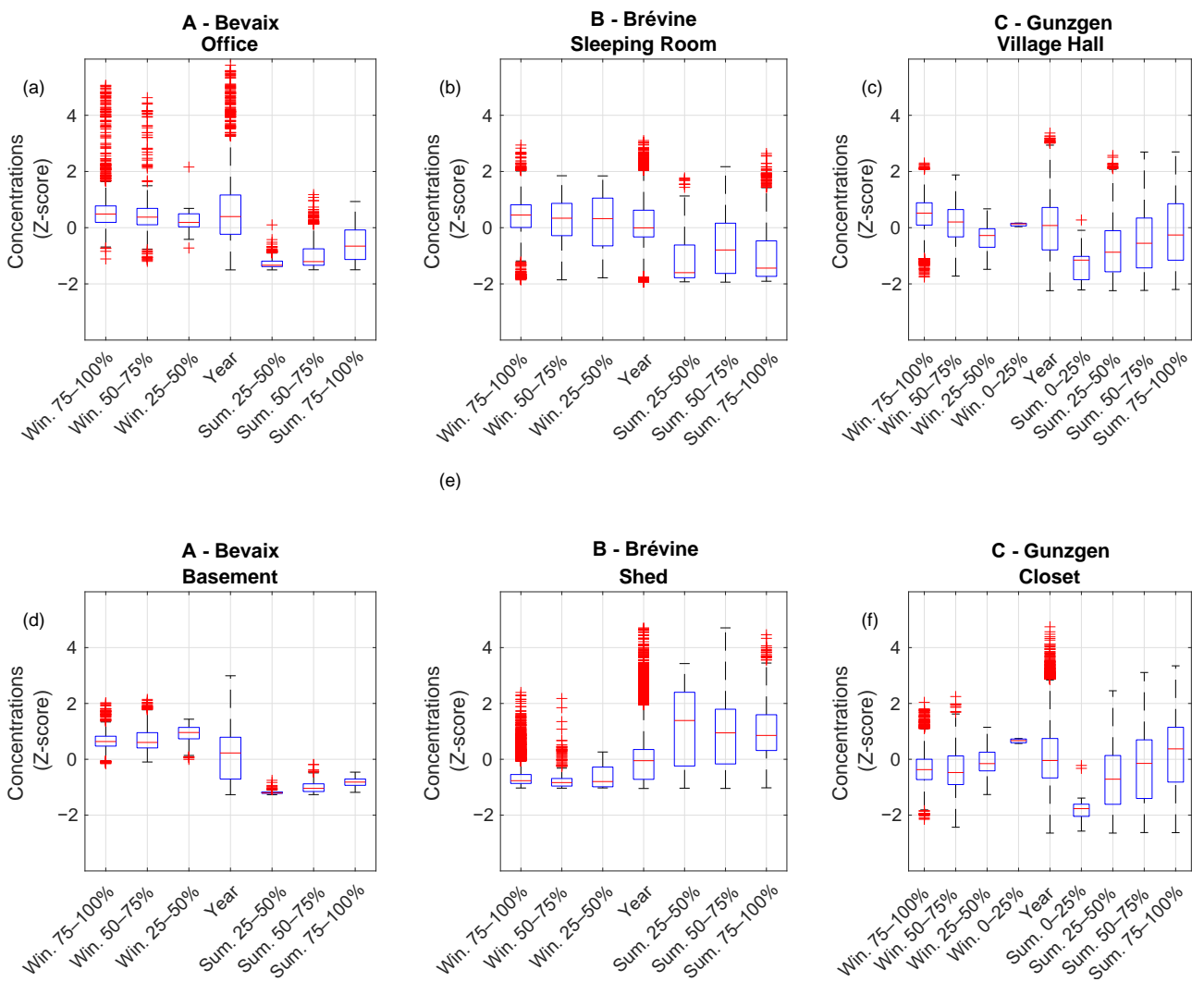

Figure 5. Box-plots synthesizing the impacts of relative humidity on IRC at Bevaix (a,d), La Brévine $(\mathbf{b}, \mathbf{e})$, and Gunzgen $(\mathbf{c}, \mathbf{f})$. Occupied spaces are shown in $(\mathbf{a}-\mathbf{c})$ and unoccupied spaces in $(\mathbf{d}-\mathbf{f})$. Relative humidity ranges are given for both winter and summer. Some of them are missing because they did not occur

\subsubsection{Westerly Winds}

Westerly winds appeared to have more pronounced seasonal effects on IRC than eastern winds, in Bevaix and La Brévine for both occupied and unoccupied spaces (cf. Figure 7). La Brévine's shed was an exception and presented high IRC during strong western wind events. This may be explained by the north-western location of this space within the building.

At Bevaix, wind speed influenced IRC more than wind direction. At La Brévine, the opposite is shown for both the sleeping room and shed: wind direction influenced IRC the most. During easterly winds, IRC seemed to decrease when wind speed increased, and during westerly winds, IRC increased when wind speed increased. At Gunzgen, the trend is similar to the one for western winds, but strong easterly winds influenced IRC more during the summer in the closet.

These results may indicate that the most influential wind parameter depends on building characteristics. Moreover, the study room location within the house may influence IRC results according to the wind direction. Indeed, the wind-induced pressure field around the house varies across different parts of the houses, meaning that IRC may potentially fluctuate differently indoors during the same wind event. This underlines the importance of building characteristics and orientation. 

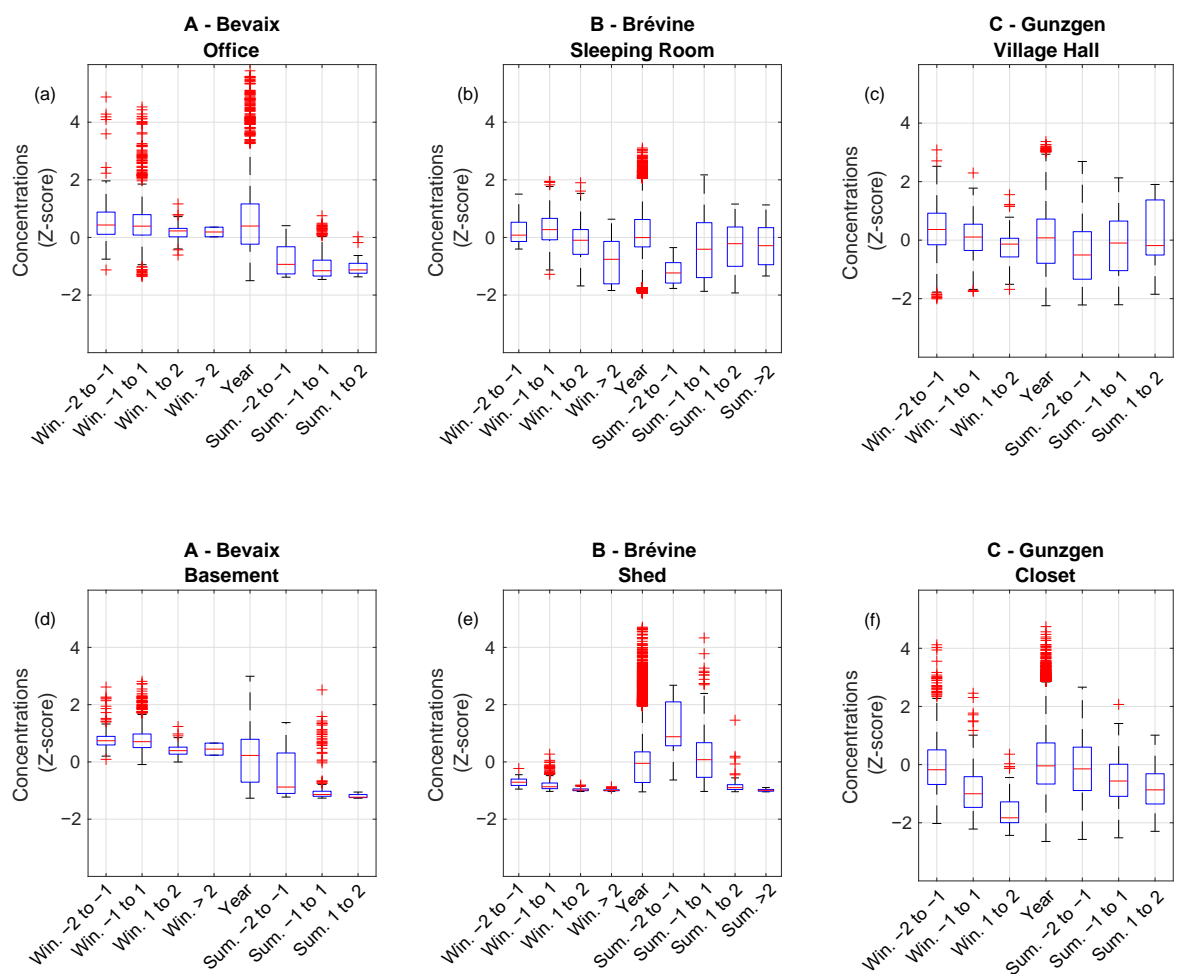

Figure 6. Box-plots synthesizing the impacts of easterly winds on IRC at Bevaix (a,d), La Brévine $(\mathbf{b}, \mathbf{e})$, and Gunzgen $(\mathbf{c}, \mathbf{f})$. Occupied spaces are shown in $(\mathbf{a}-\mathbf{c})$ and unoccupied spaces in $(\mathbf{d}-\mathbf{f})$. Annual standard deviation threshold results are given for both winter and summer. Some of them are missing because they did not occur.
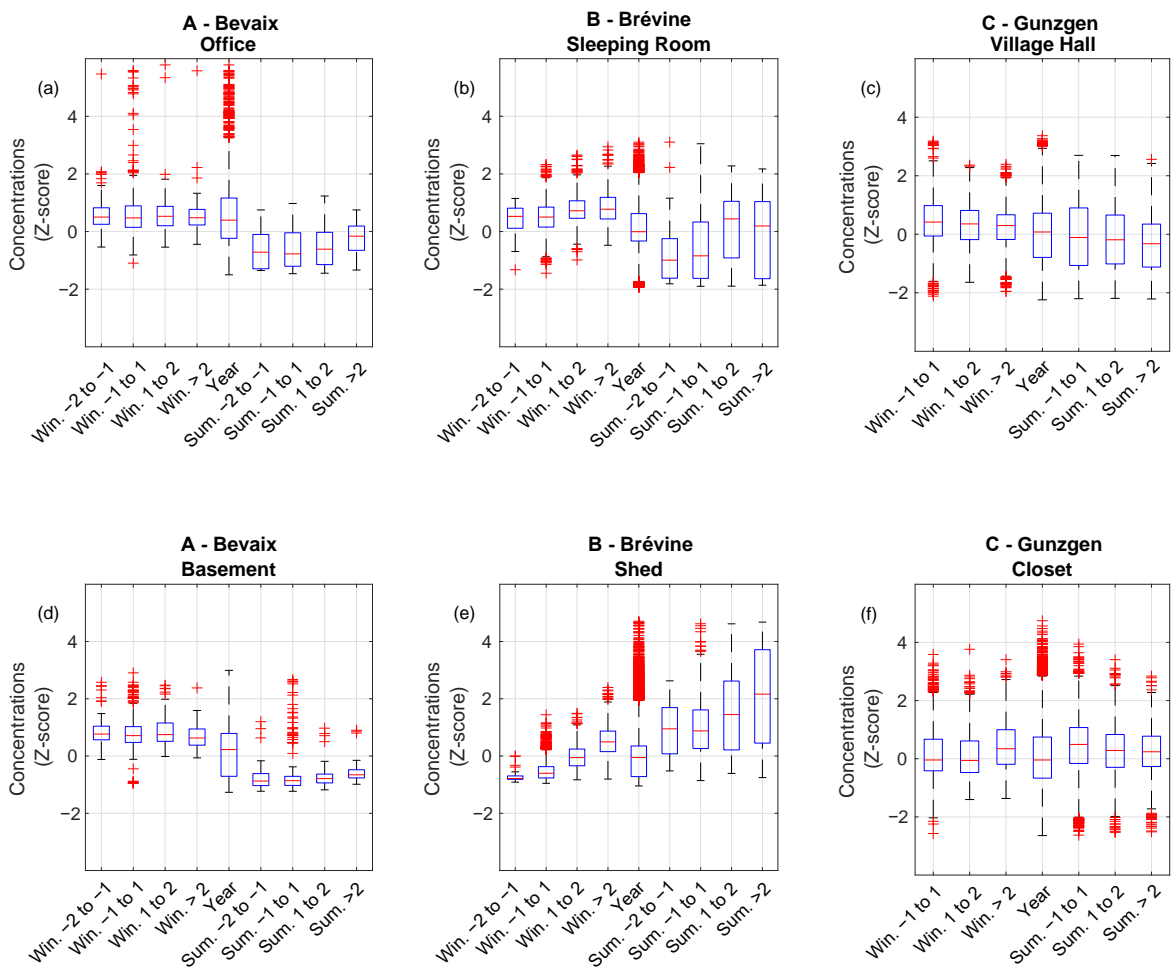

Figure 7. Box-plots synthesizing the impacts of westerly winds on IRC at Bevaix (a,d), La Brévine $(\mathbf{b}, \mathbf{e})$, and Gunzgen $(\mathbf{c}, \mathbf{f})$. Occupied spaces are shown in $(\mathbf{a}-\mathbf{c})$ and unoccupied spaces in $(\mathbf{d}-\mathbf{f})$. Annual standard deviation threshold results are given for both winter and summer. Some of them are missing because they did not occur. 


\subsection{Results Synthesis}

Table 8 presents the synthesized results found throughout the three study sites, and put them into perspective, relative to the existing literature. The present results are consistent with a previous study, carried out on the same buildings [17]. The main results show that outdoor temperature influence IRC with an anti-correlation link (-0.72), followed by precipitation (positive correlation) and wind (correlation of -0.65 ), which strongly depends on wind direction and speed. Finally, atmospheric pressure influence IRC to a lower extent compared to other meteorological parameters [17].

Table 8. Syntheses of meteorological parameter influences on IRC highlighted in this study. ACanti-correlation; $\mathrm{CO}$ - correlation; $\mathrm{DE}$ - depends on source; LI-link between parameters; /—no clear tendency.

\begin{tabular}{|c|c|c|c|c|c|c|c|c|c|}
\hline $\begin{array}{l}\text { Meteorological } \\
\text { Parameter }\end{array}$ & Threshold & $\begin{array}{c}\text { A-Bevaix } \\
\text { Occupied }\end{array}$ & $\begin{array}{l}\text { A-Bevaix } \\
\text { Unoccupied }\end{array}$ & $\begin{array}{c}\text { B-La Brévine } \\
\text { Occupied }\end{array}$ & $\begin{array}{l}\text { B-La Brévine } \\
\text { Unoccupied }\end{array}$ & $\begin{array}{c}\mathrm{C} \text {-Gunzgen } \\
\text { Occupied }\end{array}$ & $\begin{array}{l}\text { C-Gunzgen } \\
\text { Unoccupied }\end{array}$ & $\begin{array}{l}\text { Literature } \\
\text { Occupied }\end{array}$ & $\begin{array}{c}\text { Literature } \\
\text { Unoccupied }\end{array}$ \\
\hline \multirow{2}{*}{ Temperature } & Low & $\mathrm{CO}$ & $\mathrm{CO}$ & $\mathrm{CO}$ & $\mathrm{CO}$ & $\mathrm{CO}$ & $\mathrm{CO}$ & \multirow[t]{2}{*}{$\mathrm{AC}$} & \multirow[t]{2}{*}{$\mathrm{CO}$} \\
\hline & High & $\mathrm{AC}$ & $\mathrm{AC}$ & AC & $\mathrm{CO}$ & $\mathrm{AC}$ & $\mathrm{AC}$ & & \\
\hline \multirow{4}{*}{$\begin{array}{c}\text { Atmospheric } \\
\text { pressure }\end{array}$} & Winter low & / & / & / & / & / & / & \multirow[t]{4}{*}{$\mathrm{DE}$} & \\
\hline & Winter high & / & / & / & / & / & / & & \\
\hline & Summer low & / & / & / & / & / & / & & \\
\hline & $\begin{array}{c}\text { Summer } \\
\text { high }\end{array}$ & / & / & / & / & / & / & & \\
\hline \multirow{2}{*}{ Precipitation } & Winter & / & / & $\mathrm{CO}$ & $\mathrm{CO}$ & / & / & \multirow[t]{2}{*}{$\mathrm{CO}$} & \multirow[t]{2}{*}{$\mathrm{CO}$} \\
\hline & Summer & / & / & / & $\mathrm{CO}$ & / & / & & \\
\hline \multirow{2}{*}{ Drought } & Winter & $\mathrm{AC}$ & $\mathrm{CO}$ & / & / & / & / & & \\
\hline & Summer & / & / & $\mathrm{CO}$ & $\mathrm{AC}$ & $\mathrm{AC}$ & $\mathrm{AC}$ & & \\
\hline Relative & Winter & $\mathrm{CO}$ & $\mathrm{CO}$ & / & / & $\mathrm{CO}$ & $\mathrm{AC}$ & \multirow[t]{2}{*}{$\mathrm{DE}$} & \\
\hline humidity & Summer & $\mathrm{CO}$ & $\mathrm{CO}$ & / & / & $\mathrm{CO}$ & $\mathrm{CO}$ & & \\
\hline \multirow{2}{*}{ Easterly winds } & Winter & $\mathrm{AC}$ & / & $\mathrm{AC}$ & $\mathrm{AC}$ & $\mathrm{AC}$ & $\mathrm{AC}$ & \multirow{4}{*}{ LI } & \\
\hline & Summer & $\mathrm{AC}$ & $\mathrm{AC}$ & $\mathrm{CO}$ & $\mathrm{AC}$ & $\mathrm{CO}$ & $\mathrm{AC}$ & & \\
\hline \multirow{2}{*}{ Westerly winds } & Winter & / & / & $\mathrm{CO}$ & $\mathrm{CO}$ & $\mathrm{AC}$ & $\mathrm{AC}$ & & \\
\hline & Summer & $\mathrm{CO}$ & $\mathrm{CO}$ & $\mathrm{CO}$ & $\mathrm{CO}$ & $\mathrm{CO}$ & $\mathrm{AC}$ & & \\
\hline
\end{tabular}

\section{Discussion}

This paper assess meteorological parameters on IRC in order to ensure short-term radon measurement reliabilities and good interpretations in different contexts (after an official measurement, during a real-estate transaction, or before a building remediation and transformation), helping manage radon-related risks within a building. Radon measurements should give professionals relevant information on radon dynamics within buildings. On that basis, professionals would recommend constructive measures for a sustainable radon building remediation.

We used long-term radon and weather time series in order to assess meteorological parameter influences on IRC. IRC distribution comparisons, related to the recurrence of different meteorological definitions, indicate if radon is influenced by an event. This original method allowed us to validate a hypothesis issued from previous works, and provide new knowledge on IRC during droughts. Table 8 presents syntheses all the study results and puts them into perspective according to the existing literature.

Amongst all of the investigated variables, outside temperature variations seem to have an important impact on IRC. Similar behaviours have been shown in the occupied spaces at the three sites, which indicate rather robust results. When the air temperature increases, IRC decreases during the summer. Two reasons may explain this behaviour. First, the outdoor-indoor temperature difference induces a differential pressure. Pressure would be higher inside the building, implying that radon will penetrate less indoors. Secondly, during the summer, inhabitants would ventilate more frequently. Ventilation allows radon to escape to the indoor environments. During the winter, when outdoor air temperature decreases, IRC increases except for the coldest days of the year. This exception remains "unsure" due to the low icy-day samples. Moreover, radon could be trapped within frozen ground and may not reach indoor environments. Heating, which induces a stack effect, 
increases indoor radon intrusion. For both the summer and winter seasons, occupant behaviours affect IRC (i.e., heating vs ventilation).

Our results also show that precipitation events impacted IRC in different ways at each investigated site. Summer rain and thunderstorms induced an increase in IRC everywhere, except in the sleeping room at La Brévine. During high precipitation events, soils became sealed and inhibited radon exhalation. Given that soils under buildings remained unsealed, radon can diffuse in the building and, thus, cause IRC to increase [33]. Findings shown in this study corroborate these observations.

As with precipitation events, high wind events affect IRC differently at each study site. The induced pressure field around the building further impacts IRC. The sealing shell of each building is unique: this means that the effect of the same wind event will be different for each building. However, huge differences of IRC distributions are shown in this study. Wind must be taken into consideration in relation with the building's characteristics when a measure of radon is undertaken.

Atmospheric pressure and outdoor air relative humidity do not seem to be huge determinants of IRC.

Drought, which has not been highlighted in the literature, seems to influence IRC differently, according to the site and, therefore, the type of underlying ground. A unique trend cannot be issued, but this influence could be investigated in a further study since drought will be more frequent in Switzerland in the following decades [50].

\section{Conclusions}

This study shows how weather conditions impacted IRC at three different sites in Switzerland, over the long-term. Results, coming from continuous active measurements, corroborate the influence of the weather on IRC, as displayed in Table 8. However, weather conditions on IRC might be different between sites and studied spaces. Temperature and, to a lesser extent, precipitation, seems to exert more influence on IRC amongst all weather parameters and sites. By contrast, wind seems to influence IRC differently at each study site. Building characteristics and orientation may explain these differences. Based on these observations, results cannot be extended to the whole Swiss building stock. This study thus prompts for extending the long-term measurements at more sites in Switzerland, given the large diversity of weather and geological conditions.

This paper highlights the influence of different weather events on IRC and the importance for professionals to evaluate weather conditions during radon measurements. We thus recommend professionals to carry out or retrieve temperature, wind, and precipitation measurements, simultaneously, as for indoor radon. Moreover, good knowledge of the building characteristics will increase the diagnostics's accuracy. Professionals should be aware that these following conditions cause important IRC fluctuations around the yearly central tendencies and, thus, might bias measurements.

- High and low temperature extremes: temperatures govern the pace of our lives (heating period, ventilation), which induce broad variations of IRC in both occupied and unoccupied spaces.

- Thunderstorms and heavy rains: these events induce a ground water-tightness, inhibiting radon exhalation, except under houses, where soils are presumed water-free.

- Wind events: both the speed and direction of wind can affect IRC by the induced pressure-field around the building.

Some limitations are highlighted by this study: weather conditions impact IRC, but other influences-building characteristics, occupant behaviour, geology - cannot be fully excluded. This study underlines the complexity of interactions operating on IRC (cf. Figure 1). Indeed, the latter cannot be taken into account anytime during the entire study periods. To improve the results, all of these aspects should be monitored and controlled, but this requires a more thorough investigation. According to the small number of surveyed buildings and the many influences on IRC, conclusions are limited to this study's framework. Thus, this study gives a preliminary view of this problematic. 
Consequently, further studies in this field could explore the link between meteorological parameters and IRC in a fully controlled environment. Laboratory conditions and simulations of weather conditions could assess only the influence of meteorological parameters. Such a study could also assess, more precisely, the influence of outdoor atmospheric pressures and relative humidity on indoor radon concentrations.

Author Contributions: Conceptualization, J.G.P.; methodology, J.F.R.; software, J.F.R.; validation, J.F.R., S.G., M.G., M.P., F.B. and J.G.P.; formal analysis, J.F.R.; investigation, J.F.R.; resources, F.B. and J.G.P.; data curation, J.F.R.; writing—original draft preparation, J.F.R., S.G. and J.G.P.; writing—review and editing, J.F.R., S.G., M.G., M.P., F.B. and J.G.P.; visualization, J.F.R.; supervision, J.G.P.; project administration, J.G.P., F.B., M.P.; funding acquisition, J.G.P., F.B., M.P. All authors have read and agreed to the published version of the manuscript.

Funding: This research was funded within the Interreg Jurad-Bat project (2016-2020) by the Federal Office of Public Health of Switzerland. Grant number: 19.0231261434.0000-225/1.

Institutional Review Board Statement: Not applicable.

Informed Consent Statement: Not applicable.

Data Availability Statement: Restrictions apply to the availability of La Brévine and Bevaix. Data were obtained from croqAIR and are available from the authors with the permission of croqAIR. Gunzgen radon data presented in this study are available upon request from the corresponding author. The data are not publicly available due to privacy. Restrictions apply to the availability of weather conditions data. Data were obtained from MeteoSuisse and are available on the platform IDAWEB with the permission of MeteoSuisse.

Acknowledgments: We thank Corinne Hager Joerin (Heia-FR) for her advice, help, and support regarding the statistical analysis. I, Joan Rey, would like to especially thank the entire working group for the opportunity they gave me, their invaluable guidance, and their trust.

Conflicts of Interest: The authors declare no conflict of interest.

\section{Appendix A}

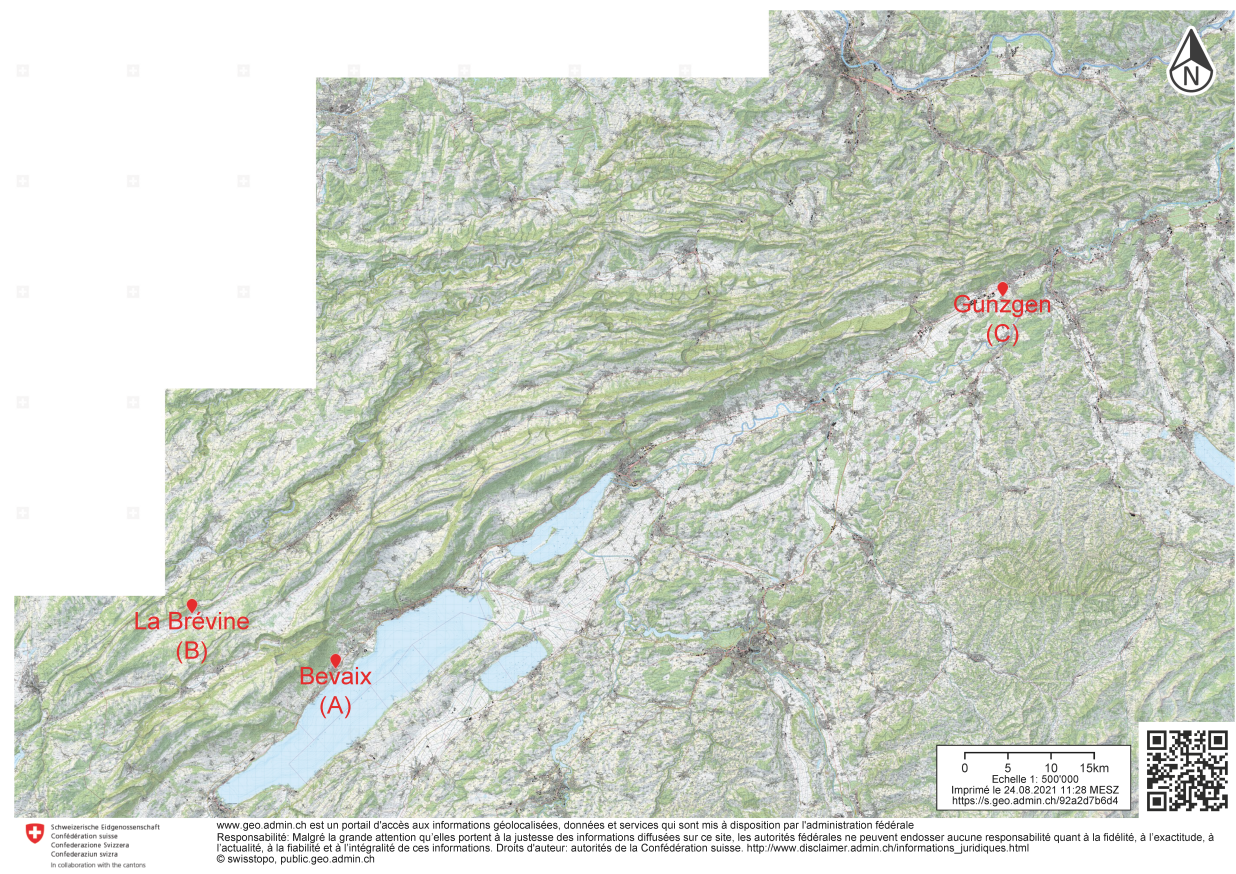

Figure A1. Map of the three study sites: Bevaix (A), La Brévine (B), Gunzgen (C). 


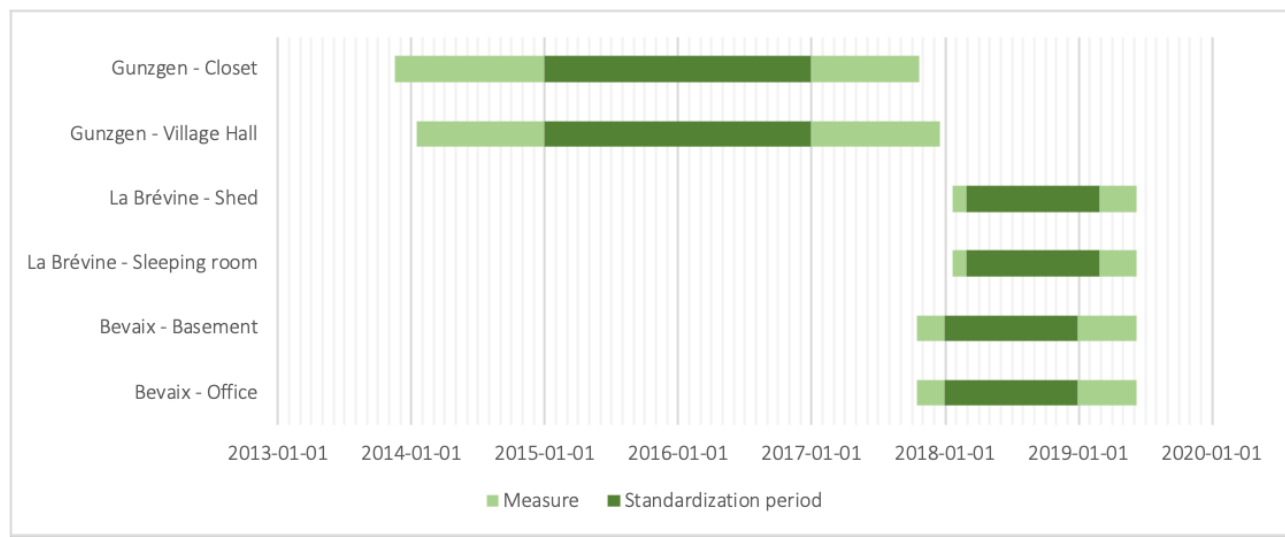

Figure A2. Timeline of the radon measurement acquisition. Dataset are standardized according to deep green periods.

Table A1. Studied buildings' geographical, geological, meteorological, built and radon characteristics.

\begin{tabular}{|c|c|c|c|}
\hline $\begin{array}{c}\text { Building } \\
\text { Municipality }\end{array}$ & $\underset{\text { Bevaix }}{\text { A }}$ & $\begin{array}{c}\text { B } \\
\text { La Brévine }\end{array}$ & $\begin{array}{c}\text { C } \\
\text { Gunzgen }\end{array}$ \\
\hline Canton & Neuchâtel & Neuchâtel & Solothurn \\
\hline Geographical location & $\begin{array}{c}\text { Swiss Plateau } \\
\text { near Neuchâtel lake }\end{array}$ & Jura mountains & Swiss Plateau \\
\hline Elevation (m. asl) & 475 & 1075 & 430 \\
\hline Lithology & $\begin{array}{l}\text { Fluvio-lacustrine } \\
\text { sediments and molasse }\end{array}$ & $\begin{array}{l}\text { Jurassic and } \\
\text { cretaceous limestones }\end{array}$ & Morainic sediments \\
\hline $\begin{array}{l}\text { Probability to be overthe } \\
\text { reference value }\left(300 \mathrm{~Bq} / \mathrm{m}^{3}\right)\end{array}$ & $4 \%$ & $69 \%$ & $15 \%$ \\
\hline $\begin{array}{l}\text { Mean temperature } \\
\text { (min.; mean; max.) [51] }\end{array}$ & $6.8 ; 10.2 ; 14^{\circ} \mathrm{C}$ & $-1.6 ; 4.9 ; 10.6{ }^{\circ} \mathrm{C}$ & $4.8 ; 9 ; 13.9^{\circ} \mathrm{C}$ \\
\hline Sum of annual rainfalls [51] & $978 \mathrm{~mm}$ & $1597 \mathrm{~mm}$ & $1129 \mathrm{~mm}$ \\
\hline Mean wind speed [51] & $2.6 \mathrm{~m} / \mathrm{s}$ & / & $1.7 \mathrm{~m} / \mathrm{s}$ \\
\hline Building type & Family house & Old Jura farmhouse & Communal building \\
\hline Construction year & 1895-1900 & 18th century & 1845 \\
\hline Building orientation & NE-SW & NE-SW & NE-SW \\
\hline Renovation & Yes & Yes, partially & Yes \\
\hline Renovation year & 2001 & - & 1976 \\
\hline Constructive system & Concrete and rubble & Rubble & Concrete \\
\hline Ground contact & Partially excavated & Slab-on-grade & Slab-on-grade \\
\hline Concrete slab & Yes, partially & Yes, partially & Yes \\
\hline Number of levels & 3 & 2 & 2 \\
\hline Unpaved space & No & Yes & No \\
\hline Approx. ACH [52] & Office: $2-5$ & Sleeping room: $2-5$ & Village hall: $2-5$ \\
\hline & Basement: 2-5 & Shed: $>10$ & Closet: $<2$ \\
\hline Ventilation mode & Natural & Natural & Natural \\
\hline Ventilation regime & Often ventilated & Often ventilated & Seldom ventilated \\
\hline Rooms relation & $\begin{array}{l}\text { One next to the second } \\
\text { with a half-stair in between }\end{array}$ & Not connected & Not connected \\
\hline Radon sensors & RadonMapper & RadonMapper & RadonMapper AlphaGUARD \\
\hline Radon measurements & 20 months & 16 months & 47 months \\
\hline
\end{tabular}

Table A2. Location and distance to study sites of the meteorological stations used in this study.

\begin{tabular}{ccccccc}
\hline & $\begin{array}{c}\text { A } \\
\text { Bevaix }\end{array}$ & & $\begin{array}{c}\text { B } \\
\text { La Brévine }\end{array}$ & \multicolumn{2}{c}{ C } \\
Gunzgen \\
\hline Variables & Station & Distance $\mathbf{( k m )}$ & Station & Distance $(\mathbf{k m})$ & Station & Distance $(\mathbf{k m})$ \\
\hline Hourly mean temperature & Boudry & 3.2 & Brévine & 1.37 & Härkingen & 0.8 \\
Hourly maximum temperature & Neuchâtel & 13.5 & Brévine & 1.37 & Härkingen & 0.8 \\
\hline
\end{tabular}


Table A2. Cont.

\begin{tabular}{|c|c|c|c|c|c|c|}
\hline & $\stackrel{\text { A }}{\text { Bevaix }}$ & & $\begin{array}{c}\text { B } \\
\text { La Brévine }\end{array}$ & & $\begin{array}{c}\text { C } \\
\text { Gunzgen }\end{array}$ & \\
\hline Variables & Station & Distance (km) & Station & Distance (km) & Station & Distance $(\mathbf{k m})$ \\
\hline Hourly minimum temperature & Neuchâtel & 13.5 & Brévine & 1.37 & Härkingen & 0.8 \\
\hline Hourly mean relative humidity & Boudry & 3.2 & Brévine & 1.37 & Härkingen & 0.8 \\
\hline Hourly mean pressure asl. & Neuchâtel & 13.5 & Brévine & 1.37 & Härkingen & 0.8 \\
\hline Hourly precipitation sum & Boudry & 3.2 & Brévine & 1.37 & Härkingen & 0.8 \\
\hline Thunderstorm & Neuchâtel & 13.5 & Brévine & 1.37 & / & / \\
\hline Hourly snowfall & Neuchâtel & 13.5 & La Chaux-De-Fond & 18.8 & / & / \\
\hline Hourly mean wind direction & Boudry & 3.2 & Brévine & 1.37 & Härkingen & 0.8 \\
\hline Hourly mean wind speed & Boudry & 3.2 & Brévine & 1.37 & Härkingen & 0.8 \\
\hline
\end{tabular}

Table A3. Technical characteristics of radon sensors used in this study.

\begin{tabular}{ccc}
\hline Sensor & RadonMapper [53] & AlphaGUARD [54] \\
\hline Producer & Tecnavia SA & Bertin Instruments \\
Country & Switzerland & France \\
Radon detection method & Scintillation cells & Ionization chamber \\
Range $\left(\mathrm{Bq} / \mathrm{m}^{3}\right)$ & 10 to $3,000,000$ & 2 to $2,000,000$ \\
Accuracy & $0.035 \mathrm{cpm}$ at $1 \mathrm{~Bq} / \mathrm{m}^{3}$ & $5 \mathrm{cpm}$ at $100 \mathrm{~Bq} / \mathrm{m}^{3}$ \\
Sampling rate & $1 \mathrm{~min}$ & $10 \mathrm{~min}$ \\
Certified by METAS & YES & YES \\
\hline
\end{tabular}

\section{References}

1. Commission Romande de Mathématique, Physique et Chimie. Formulaires et Tables: Mathématiques, Physique, Chimie; Editions G d'Encre: Le Locle, Switzerland, 2012.

2. World Health Organization. (Ed.) WHO Handbook on Indoor Radon: A Public Health Perspective; World Health Organization: Geneva, Switzerland, 2009.

3. FOPH; FAKTOR Verlag AG. Radon Manuel Pratique; Beltz Verlag: Weinheim, Germany, 2018.

4. Kropat, G.; Bochud, F.; Jaboyedoff, M.; Laedermann, J.P.; Murith, C.; Palacios, M.; Baechler, S. Major influencing factors of indoor radon concentrations in Switzerland. J. Environ. Radioact. 2014, 129, 7-22. [CrossRef] [PubMed]

5. IRSN. Radioactivité et Environnement; Rapport Scientifique et Technique 2008; IRSN: Paris, France, 2009.

6. FOPH. Radon Map; Federal Office of Public Health: Liebefeld, Switzerland, 2017.

7. Parriaux, A.; Turberg, P.; Gandolla, M. Géologie et Santé Publique: Contamination au Radon; TRACÉS: Zürich, Switzerland, 2010; Volume 5/6.

8. FOPH. Manuel Suisse du Radon; Federal Office of Public Health: Bern, Switzerland, 2007.

9. Cinelli, G.; Čeliković, I.; Gruber, V.; Nikolić, J.; Pantelić, G.; Vukanac, I.; Živanović, M.; European Commission; Joint Research Centre. Literature Review of Indoor Radon Surveys in Europe; Publications Office of the European Union: Luxembourg, 2018.

10. Phong Thu, H.N.; Van Thang, N.; Hao, L.C. The effects of some soil characteristics on radon emanation and diffusion. J. Environ. Radioact. 2020, 216, 106189. [CrossRef] [PubMed]

11. Bruno, R.C. Sources of Indoor Radon in Houses: A Review. J. Air Pollut. Control. Assoc. 1983, 33, 105-109. [CrossRef]

12. FOPH. National Action Plan concerning Radon 2012-2020; Federal Office of Public Health: Liebefeld, Switzerland, 2011.

13. FOPH. Federal Office of Public Health: Radon Action Plan 2021-2030; Federal Office of Public Health: Liebefeld, Switzerland, 2020.

14. Darby, S.; Hill, D.; Deo, H.; Auvinen, A.; Barros-Dios, J.M.; Baysson, H.; Bochicchio, F.; Falk, R.; Farchi, S.; Figueiras, A.; et al. Residential radon and lung cancer-Detailed results of a collaborative analysis of individual data on 7148 persons with lung cancer and 14,208 persons without lung cancer from 13 epidemiologic studies in Europe. Scand. J. Work Environ. Health 2006, $32,1-84$.

15. European Society of Radiology (ESR). Summary of the European Directive 2013/59/Euratom: Essentials for health professionals in radiology. Insights Imaging 2015, 6, 411-417. [CrossRef]

16. International Atomic Energy Agency. Radioprotection et Sûreté des Sources Rayonnements: Normes Fondamentales Internationales de Sûreté; International Atomic Energy Agency: Vienna, Austria, 2016.

17. Rey, J.; Goyette, S.; Palacios, M.; Barazza, F.; Gandolla, M.; Goyette Pernot, J. Influence of some specific meteorological events on indoor radon dynamic in western Switzerland. J. Phys. Conf. Ser. 2021, 2042, 012138. [CrossRef]

18. Pearson, J.E.; Jones, G.E. Soil concentrations of "emanating radium-226" and the emanation of radon-222 from soils and plants. Tellus 1966, 18, 655-662. [CrossRef]

19. Ramola, R.C.; Kandari, M.S.; Negi, M.S.; Choubey, V.M. A Study of Diurnai Variation of Indoor Radon Concentrations. Jpn. J. Health Phys. 2000, 35, 211-216. [CrossRef] 
20. Rowe, J.E.; Kelly, M.; Price, L.E. Weather system scale variation in radon-222 concentration of indoor air. Sci. Total Environ. 2002, 284, 157-166. [CrossRef]

21. Curado, A.; Silva, J.; Carvalho, L.; Lopes, S.I. Indoor Radon concentration assessment in a set of single family houses: Case study held in Barcelos, North of Portugal. Energy Procedia 2017, 136, 109-114. [CrossRef]

22. Xie, D.; Liao, M.; Kearfott, K.J. Influence of environmental factors on indoor radon concentration levels in the basement and ground floor of a building-A case study. Radiat. Meas. 2015, 82, 52-58. [CrossRef]

23. Groves-Kirkby, C.; Denman, A.; Crockett, R.; Phillips, P.; Gillmore, G. Identification of tidal and climatic influences within domestic radon time-series from Northamptonshire, UK. Sci. Total Environ. 2006, 367, 191-202. [CrossRef]

24. Groves-Kirkby, C.J.; Crockett, R.G.; Denman, A.R.; Phillips, P.S. Climatic and seasonal influences on radon time series in an environment of low anthropogenic activity. In Proceedings of the 13th International Congress of the International Radiation Protection Association (IRPA13), Glasgow, UK, 14-18 May 2012.

25. Hubbard, L.; Hagberg, N.; Enflo, A. Temperature Effect on Radon Dynamics in Two Swedish Dwellings. Radiat. Prot. Dosim. 1992, 45, 381-386. [CrossRef]

26. Yu, K.N.; Young, E.C.M.; Li, K.C. A Study of Factors Affecting Indoor Radon Properties. Health Phys. 1996, 71, 179-184. [CrossRef]

27. Kitto, M.E. Interrelationship of indoor radon concentrations, soil-gas flux, and meteorological parameters. J. Radioanal. Nucl. Chem. 2005, 264, 381-385. [CrossRef]

28. Jo, J.H.; Lim, J.H.; Song, S.Y.; Yeo, M.S.; Kim, K.W. Characteristics of pressure distribution and solution to the problems caused by stack effect in high-rise residential buildings. Build. Environ. 2007, 42, 263-277. [CrossRef]

29. Porstendorfer, J.; Butterweck, G.; Reineking, A. Daily Variation of the Radon Concentration Indoors and Outdoors and the Influence of Meteorological Parameters. Health Phys. 1994, 67, 283-287. [CrossRef] [PubMed]

30. Robinson, A.L.; Sextro, R.G. Radon Entry into Buildings Driven by Atmospheric Pressure Fluctuations. Environ. Sci. Technol. 1997, 31, 1742-1748. [CrossRef]

31. Hintenlang, D.E.; Al-Ahmady, K.K. Pressure Differentials for Radon Entry Coupled to Periodic Atmospheric Pressure Variations. Indoor Air 1992, 2, 208-215. [CrossRef]

32. Marley, F. Investigation of the influences of atmospheric conditions on the variability of radon and radon progeny in buildings. Atmos. Environ. 2001, 35, 5347-5360. [CrossRef]

33. Mose, D.G.; Mushrush, G.W.; Chrosniak, C.E.; Morgan, W.F. Seasonal indoor radon variations related to precipitation. Environ. Mol. Mutagen. 1991, 17, 223-230. [CrossRef]

34. Steck, D.J. Annual average indoor radon variation over two decades. Health Phys. 2009, 96, 37-47. [CrossRef]

35. Oke, T.R.; Mills, G.; Christen, A.; Voogt, J.A. Urban Climates; Cambridge University Press: Cambridge, UK, 2017.

36. Neufert, P.; Neff, L. Gekonnt Planen—Richtig Bauen: Haus, Wohnung, Garten; mit 108 Tabellen, 495 Fachbegriffen; Vieweg: Braunschweig, Germany, 1996.

37. Vittone, R. Bâtir: Manuel de la Construction; Presses Polytechniques et Universitaires Romandes: Lausanne, Switzerland, 2013.

38. Buchli, R.; Burkart, W. Main sources of indoor radon in the swiss central Alps. Sci. Total Environ. 1985, 45, 425-432. [CrossRef]

39. Miles, J. Temporal Variation of Radon Levels in Houses and Implications for Radon Measurement Strategies. Radiat. Prot. Dosim. 2001, 93, 369-375. [CrossRef] [PubMed]

40. Crameri, R.; Furrer, D.; Burkart, W. Indoor Radon Concentrations in the Southeastern Alpine Area of Switzerland. Radiat. Prot. Dosim. 1988, 24, 237-240. [CrossRef]

41. Yang, S.; Goyette Pernot, J.; Hager Jörin, C.; Niculita-Hirzel, H.; Perret, V.; Licina, D. Radon Investigation in 650 Energy Efficient Dwellings in Western Switzerland: Impact of Energy Renovation and Building Characteristics. Atmosphere 2019, 10, 777. [CrossRef]

42. Yang, S.; Pernot, J.G.; Jörin, C.H.; Niculita-Hirzel, H.; Perret, V.; Licina, D. Energy, indoor air quality, occupant behavior, selfreported symptoms and satisfaction in energy-efficient dwellings in Switzerland. Build. Environ. 2020, 171, 106618. [CrossRef]

43. Barazza, F.; Gfeller, W.; Palacios, M.; Murith, C. An investigation of the potential causes for the seasonal and annual variations in indoor radon concentrations. Radiat. Prot. Dosim. 2015, 167, 75-81. [CrossRef] [PubMed]

44. Kropat, G.; Bochud, F.; Jaboyedoff, M.; Laedermann, J.P.; Murith, C.; Palacios (Gruson), M.; Baechler, S. Predictive analysis and mapping of indoor radon concentrations in a complex environment using kernel estimation: An application to Switzerland. Sci. Total Environ. 2015, 505, 137-148. [CrossRef] [PubMed]

45. Tuia, D.; Kanevski, M. Indoor radon distribution in Switzerland: Lognormality and Extreme Value Theory. J. Environ. Radioact. 2008, 99, 649-657. [CrossRef] [PubMed]

46. Hauri, D.D.; Huss, A.; Zimmermann, F.; Kuehni, C.E.; Röösli, M. A prediction model for assessing residential radon concentration in Switzerland. J. Environ. Radioact. 2012, 112, 83-89. [CrossRef] [PubMed]

47. MétéoSuisse. Portail de Données Pour L'enseignement et la Recherche-MétéoSuisse; MétéoSuisse: Kloten, Switzerland, 2021.

48. MétéoSuisse. Le Climat Suisse en Détail_MétéoSuisse; MétéoSuisse: Kloten, Switzerland, 2021.

49. MétéoSuisse. Roses des Vents par Station-MétéoSuisse; MétéoSuisse: Kloten, Switzerland, 2021.

50. Fischer, A.M.; MétéoSuisse. Scénarios Climatiques Pour la Suisse: CH2018; National Centre for Climate Service (NCSS): Zurich-Flughafen, Switzerland, 2018.

51. MétéoSuisse. Normes par Paramètre-MétéoSuisse; MétéoSuisse: Kloten, Switzerland, 2021.

52. Vent-Axia. Vent-Axia Ventilation Design Guidelines; Vent-Axia: Crawley, UK, 2021. 
53. TECNAVIA SA. RadonMapper; Tecnavia: Lugano, Switzerland, 2014.

54. Bertin Instruments SAS. AlphaGUARD—L'expertise Radon à Portée de Main; Bertin Technologies SAS: Montigny Le Bretonneux, France, 2017. 